\title{
Promoting WICO 2.0 from PT. Telkom Surabaya Mergoyoso,Tbk to the Customers by Using a Promotional Video
}

\author{
Diondi Mereki Menteng \\ English Department, Faculty of Languages and Literature, Petra Christian University, Siwalankerto 121- \\ 131, Surabaya 60236, INDONESIA \\ E-mails: Diondi.mereki43@gmail.com
}

\begin{abstract}
This Business Communication Final Project (BCFP) is made for PT. Telkom Surabaya mergoyo,tbk, a company which offers service in telecommunications and internet service provider in Indonesia. The problem of the project is how to promote the products and services that Wico 2.0 offers. Using the BCFP, the promotional video will be able to help the marketing and the sales to sell the company's product and also make the customers aware with the uniqueness of the products. The promotional video contains the products of Wico 2.0 and the Uniqueness of Wico 2.0 itself. The video shows facilites of Wico 2.0. The promotion video also explains the benefits of Wico 2.0. Using this BCFP, the customers will be know more about Wico 2.0. The video can also help the marketing and sales team to sell Wico 2.0, so that they can increase the sale of Wico 2.0 .
\end{abstract}

Keywords: A promotional video, Wico 2,0, Telkom Indonesia, advertising

\section{INTRODUCTION}

Wico 2.0 or Wifi corner 2.0, is a WiFi.id service for the public held by Telkom in collaboration with Micro, Small and Medium Enterprises (MSMEs). Different with the others product that Telkom had, Wico provides an internet service from up to $100 \mathrm{mbps}$ for each person by using a voucher to access it. The modem of Wico 2.0 will be given free to the customers who are interested in. To access its product the costumers need top up its voucher. For the first customers, they have to top up the voucher for Rp.500.000.- After top up the voucher will be added to the modem owner account. The first voucher will have a time period usually like two until three month, if the voucher has reached its limit, the owner needs to top up again, and for the next top up is up is not five hundred anymore but based on the owner need. If the five hundreds voucher is still on the account and it is going to reach up the time limit period, the owner can top up only for 10.000 and continually to use the modem. To use the owner modem, the owner will be given an application and account created by Telkom to access and monitor wico 2.0 with their gadget. For the customers, if they want to use the voucher, they need to log in on the internet page that will immediately show up after it connected to the modem. The voucher of Wico 2.0 has a time limit up to 2 hours only for each voucher. The 2 hours voucher costs 3.500 by Telkom and it is up to the owner modem to sell it to other people with different prices. When the voucher time reaching the time limit, the customers are no longer can access the internet and they need to buy the new voucher again from the modem owner. This is why Wico modem is best to be put on school, café or event that many people attend. I have seen that there is a problem in the field of marketing of Wico 2.0. First of all, Wico 2.0 is a new brand from Telkom, and in my internship when the sales team promoted Wico 2.0 to the IT team at SMKN 7 Surabaya when doing a sales call, the customers were still confused with Wico 2.0. The customers still didn't understand the function or benefits of Wico 2.0. Furthermore, the only tool the sales team use to describe this product is only explanation. This problem makes this product unable to be sold very well and the result is, the salesperson cannot reach the sales target because the customers still did not understand what Wico 2.0 is. So, I decided to make a 
marketing tool to boost its advertisement and it will be very useful for the company, especially for the sales marketing and for a marketing tool of its product.

This promotional video will give three advantages to Telkom Indonesia Surabaya. First, the promotional video will be a tool for Sales and Marketing to help them promote Wico 2.0. Second, the promotional video can increase the customers' awareness to know more about Telkom indonesia Surabaya products, especially wico 2.0. The last advantage is that promotional video will help the regular customers who usually use normal internet service at their business to upgrade their Wifi with wico 2.0 and get the advantages.

\section{PRINCIPLES USED IN DESIGNING THE BUSINESS COMMUNICATON TOOLS}

After the three month internship at Telkom Surabaya from September to November, I decided to make a sales tools video which focusing on function of Wico 2.0, the uniqueness and the benefits from its product. To make and finish this project completely, I use some information from online sources to understand about the definition, purposes, and features used in making a promotional video video.

\subsection{Promotion}

According to cuellar (2013, p.4), promotion is a way to introduce products or services to customers. Promotion is the most effective way to let the customers understand about the products and to let our products to be known by a lot of people.

\subsection{The definition of Promotional video}

According to an online article of the definition of a promotional video in Wisegeek(2017) defines "Promotional videos are marketing and sales tools designed to introduce or educate consumers about a particular product, cause, or organization. In order to generate additional interest of the viewers, a promo video is generally structures to be precise, direct and to only last for no more than ten to fifteen minutes."

From the definition above I can conclude that promotional video is a tool to promote a product through any Media, including online Media. In order to make the customer or viewer interest to watch the whole promotion video, the video should be at least less than ten to fifth minutes. The promotion video also should be direct and shows the benefits of the product.

\subsection{The Objective of Promotional Video}

According to McCabe (2009) ,p30, "argues that there is an objection for promotional goal setting to target the Marketing goals, which means to reach the achievement of sales of the product to consumers, the promotional video should have an ideal target market for the product.

Based on online article of "Objectives of Promotional Strategies" (2014) by Rick. There are two objectives to of promotional video.

1. Building brand awareness

Based on the definition I conclude that promotional video can be a great tool to increase the brand awareness to the customers since it designed to capture the attention of public consume.

2. Increasing sales and profits 
I conclude that promotion video is also a great tool to market a product since promotional video can emphasize what is the product about better to the customers.

\subsection{Brand and Branding Definition}

American Marketing Association defines (1960) brand as "A name, term, design, symbol, or a combinationof them, intended to identify the goods or services of one seller or group of sellers and to differentiate them from competitors." Which means brand is a design, sign or symbol of a product to create identities in order to differentiate it from the others.

Based on Kotler \& Keller(2015) "Branding is endowing products and services with the power of a brand" Kotler \& Keller: Marketing Management (2015) which means for the main aim of branding is to create a strong presence in a market which will attracts customers tol become loyal to this product/company. Branding is a important process which will involves constant attention of company and product personality to the public. Branding also something that can triggers the emotions and minds of people, it can create the attention and show who are the company and to create a good identity from its competitors.

\subsection{Types of Marketing Tools.}

There are many ways to deliver and promote a company, products, or services to customers. According to Mullin (2010, p.30) I will be using advertising tool which is time in broadcast as my business communication final project. Time in broadcast that I will use is promotion video. The reasons are promotion video not only provides information but it also provides some visual presentation to support.

\subsection{The steps for Making Good Promotional Video}

Based on online article in "The steps for making a good promotional video" by Annie Maguire (2016) defines that there are several steps for making good video. This steps are really helpful for starting make a promotional video for Telkom Indonesia. For my promotional video my goal here is to educate and to build the brand awareness to the customers. The first step my promotional video will include an educating content about the product and how to use the product is. Next, for the direction of my promotion video, I will choose three methods above which my promotion video will include a narrative content in conflict and solution. It also will include the drive action to make the customers to do something. The next step, it will include the showcase of a specific product and feature. For the tone on the promotional video, I will use straight forward and informative tone. Since my promotional video is for a business company, straight forward and informative tone can be most suitable tone for the video. It also will represent classy and professionalism advertisement. The goal is to increase the brand awareness to the customers and the video will be use for online or offline advertisement. Since it is created that way, the duration of the promotion video that I will use is no more less than one minute and the maximum three minutes. For video style I will choose a video style based on my company needs. In order to create a good visual presentation of the product to the customers, the video style I will be use in the promotional video is real people and life action style. It can create a good presentation and help the marketing to explain the product easily. The promotional video will also include many scenes; different characters and voice aver style. It will also show the use of the product and will highlight the product benefits. For the last step, I will write the video script, the video script will help the promotion video to have a story and it can help to explain what the advertisement is about. The script will not be long instead it will be short and clear.

For the Business Communication Final Project, I decided to make a promotional video. The reason why I make this promotional video is because the content in the video attract customers 
and make them have better understanding about wico 2.0 Then, doing a promotion through a video is more effective and fun compared to the last sales kit like brochure or mouth explanation. Therefore, it is essential to make this promotional video to help the Sales and Marketing team for selling wico 2.0 easily and get recognize by more people.

The models that I used for promotional video are Ade Oktaviani and the other cameo appearance that help to make the video successful from Zybric and Telkom team. Ade Oktaviani is a freelancer model at $\mathrm{W}$ modeling agency who is currently 23 years old who has been modeling for less than 2 years. The reason why $i$ choose Ade as my model because she is one of my closed friend, I ask her to help me out because she is one that I can trust and she has been modeling for 2 years with experience of basic acting and photo shoot. As a result, to get the video as I want, she is able to follow my direction and expression that given in the video. She understands on how to create a classy vibe in front of the camera and follow up the story board within her experience of modeling. In the video she is using a casual "no make-up" makeup look and apron from zybrick café to show that her appearance as the owner of the café.

For the other cameo, which is Ade friends in the video, I use Puthe and avhoy. Both of them are Ade junior which willing to help me for my video. In the video their appearance will help the story to create a café atmosphere. The next one is the security at Telkom Surabaya. The security itself Is a Telkom official staff where he was ask by the manager to help me created the video. His scene is only welcoming ade at Telkom. The third cameo is helped by Mr. Deden, Telkom brokers and marketing team. As he was informed in my internship report, he was also aske by the manager to help me created the video. His role is to explain about Wico to Ade as the customers. For the customers and cashier at Zybric, the cashier and customers are willing to help me to make the video for free since I ask them nicely and say the video was for my thesis. And the last one is the narration voice, the voice over is helped by Edvan Dika team which is my junior at Petra Christian University.

For the content of promotional video, I choose three important components, such as the opening story of Ade and her friends, the building and place and also function and benefits of wico. First, I decided to use those components because they contain a lot of information needed by the potential customers in order to know more about Wico 2.0. Customers are usually do not know or even understand Wico 2.0 Those components are considered as very important to be included in promotional video.

In addition, the order of the components included in the promotional video also becomes one of the important points that will be my consideration in making this promotional video. Based on the order of importance from not-so important into the most important scene, I put the scene "Ade with her friends" to open up a mood of viewers to follow up the video and create a little curiosity in viewers point of view. After the opening scene, it will continue to the brochure scene where I think it will make the story more interesting and show up more curiosity to the viewers.

Secondly, the scene is about Telkom Mergoyo building, where I put the location clearly and the Telkom atmosphere so the viewers will easily know this is about Telkom products. For showing the location, I want to show the viewers that they can but Wico 2.0 at Telkom Mergoyo. Furthermore, for the café scene, I choose café as the place to put the Wico products is to show the customers that Wico is best to put in where people tend to attend. Café can be the best example to be showed to the viewers of the promotional video.

Last, I put information, benefits and function about Wico 2.0. With a follow up video I put up a narration text to explain better. At first I want to put a text but i changed it to be a narration voice over to make the video more interesting, since the video I almost 2 minutes. The voice 
narration can be more effective since the video is long enough and it can bore the viewer if the watch the video and reading. Moreover, the narration voice makes the video shorted and better to explain the video.

Based on the order of importance, the customers who watch this promotional video will have an impression of getting interesting complete short story about wico in the end of video. Starting from The story and building or place, the function and the benefits, and the narration text that help the video more classy.

\section{CONCLUSION}

The main problem that PT.Telkom Indonesia Surabaya Mergoyoso faced was the Wico 2.0 were not selling very well compared to Indihome or Astinet. The sales and marketing person cannot sell Wico 2.0 well because they did not have the sales tool about Wico 2.0. Besides that, most of the customers do not know that Wico 2.0 could help them with their micro business or want to start a small busnisses. Wico 2.0 sales kit and brochure mostly contain simple information which not let the readers to understand better the benefits and its function.

First, I made and presented the proposal then negotiate the price. Next, I made the concept and script which went through a lot of revisions. I did some research in order to get some of the unique selling points and write the content. Next, I had to explain my idea to the staffs of Wico 2.0 so that the content of the promotional video will go well. Finally, after I got all the data, I started to plan for the shooting and subtitles. I arranged the concept, contents and hired the models. The draft that I made was helped by my advisor to ensure it was the best that I could give to the PT. Telkom Indonesia Surabaya Mergoyoso.

The promotional video is hoped to be a beneficial tool for PT.Telkom Indonesia Surabaya. The Sales and Marketing team can use the promotional video to give them facility in selling Wico 2.0 well. Furthermore, the promotional video will help the customers who watch this video to know more about Wico 2.0, especially the benefits and its function. The last advantage is, the promotional video will help the marketing team to promote Wico not only when they have a visit call but also can be put through live advertistment or a social media in order to boost the customers recognition about Wico 2.0 .

My suggestion for the next EBC students who will do a similar project in the future is to arrange time wisely and not to procastinate in doing this project. They should organize everything in detail because unexpected things might happen. Last, they should find a good company for their internship, because they have to sharpen the skills that they got in English Business

Communication in a good company.

\section{REFERENCES}

Aguire, M. (2016). The steps for making a good promotional video. Retrieved from https://medium.com/swlh/how-to-create-a-promotional-video-707fa7a63019

American Marketing Association. (1960). A Glossary of Marketing Terms. Chicago: American Marketing Association.

Cuellar, S. (2013). The mix of promotional. Marketing Module 8: Promotion. New York: Cornell

Kotler \& Keller (2011). Marketing Management $\left(14^{\text {th }} e d\right)$. London: Pearson Prentice Hall

McCabe, S. (2009). Marketing Communications in Tourism and Hospitality: Concepts,

Strategies, and cases. Oxford: Butterworth-Heinemann. 
Mullin, R. (2010). Sales Promotion: How to creat, implment, and integrate campaign that really work. London England:Kogan Page publishers.

Rick. (2014, May 4). Objectives of Promotional Strategies. Retrieved from https://smallbusiness.chron.com/objectives-promotional-strategies-21929.html Wisegeek. (2017, February 28). The definition of Promotional video. Retrieved from https://www.wisegeek.com/what-is-a-promotional-video.htm 